\title{
Differences in Work Values by Gender, Marital Status, and Generation: An Analysis of Data Collected from "Working Persons Survey, 2010”
}

\author{
Yutaka Ueda (Corresponding author) \\ Faculty of Economics, Seikei University \\ 3-3-1, Kichijoji-kitamachi, Musashino, Tokyo 180-8633, Japan \\ Tel: +81-422-373589Ｅ-mail: ueda@econ.seikei.ac.jp
}

\section{Yoko Ohzono}

Faculty of Contemporary Policy Studies, Josai University

1-1, Keyakidai, Sakado, Saitama 350-0295, Japan

E-mail: yoko.ohzono@nifty.com

\author{
Accepted: March 30, 2013 Published: May 21, 2013 \\ Doi:10.5296/ijhrs.v3i2.3131ＵRL: http://dx.doi.org/10.5296/ijhrs.v3i2.3131
}

\begin{abstract}
Work values have received a significant amount of attention from organizational researchers. This study performed an exploratory factor analysis of data collected from working persons living in the Tokyo metropolitan area. It identified four basic work values: accomplishment, contribution, power and authority, and monetary rewards. This study also examined the effects of gender, marital status, and generation on work values. The results revealed that males had higher levels of work values than females, except for monetary rewards. Married persons demonstrated higher levels of work values than unmarried persons did. Age exerted complicated effects on each work value. This study proposes some implications for practical applications of the results for human resource management and provides suggestions for future research.
\end{abstract}

Keywords: Work values; Gender; Age; Japanese working persons

\section{Introduction}

Working persons perform tasks with the expectation of receiving important rewards in return for their efforts. The majority of working persons desire higher wages, respected positions, good relationships with coworkers and supervisors, and comfortable work environments. However, each individual places a different emphasis on the values they might receive from work. People aim for different rewards based on their divergent work values. Work values have received a significant amount of attention in organizational research studies, particularly 
among Western scholars.

2013, Vol. 3, No. 2

In general, work values can be defined as each worker's desired outcomes from his/her work. For example, some working persons might believe that monetary rewards are the most important outcomes of work. Other workers might emphasize intrinsic rewards, such as self-growth, attainment, and recognition from others, rather than monetary or extrinsic rewards. Work values, which can be considered one of several sub-dimensions of each person's general values, remain relatively stable for long periods. However, this does not imply that work values never change. Organizational researchers have studied work values as antecedents of attitudinal and behavioral factors. Studies have also examined the impact of demographic and personality factors, which are believed to be more stable factors, on work values (Ueda \& Ohzono, 2012). In fact, some researchers have stated that work values differ based on workers' demographic factors (e.g., gender and generation).

In comparison to Western studies that examined work values, only a few studies have focused on the work values of Japanese working persons. Thus, knowledge of the kinds of work values currently possessed by current Japanese working persons and the impact of factors such as gender and generation on these different values remains limited. The present study hopes to discover the dimensionality of work values. It investigates differences in work values by gender, marital status, and generation, based on data collected from individuals who work in organizations located in the Tokyo metropolitan area. The results of this study might be used by organizations to improve human relations management. Further, although this study is not a cohort analysis, the results can be used to infer how work values change as working persons age and gain more experience.

\section{Work Values and Their Dimensionality}

A number of definitions of work values have been developed by a variety of organizational researchers. For example, Duffy (2010) defined work values as "what a person wants out of work in general and also what components of a job are important to his or her work satisfaction" (p. 52). Hattrup, Mueller, and Joens (2007) defined work values as "beliefs about the desirability of specific outcomes of working" (p. 481). Further, Dose (1997) considered work values to be "evaluative standards associated with work or the work environment by which individuals determine what is 'right' or assess the importance of preferences" (p. 228). As shown in these definitions, the concept of work values is rather abstract. Therefore, many researchers have attempted to establish a number of dimensions of work values. The most typical classification of work values is a two-category system used to describe intrinsic and extrinsic work values (Gahan \& Abeysekera, 2009; Hegney, Plank, \& Parker, 2006; Hirschi, 2010; Vansteenkiste et al., 2007). Other researchers have adopted more complicated classifications that differentiate between three and over ten kinds of work values (Carruthers, 1968; Elizur, 1984; Wang, Chen, Hyde, and Hsieh, 2010; Zhang, Wang, Yang, \& Teng, 2007; Hagstrom \& Kjellberg, 2007; Hattrup, Muller, \& Aguirre, 2007; Van Ness, Melinsky, Buff, \& Seifert, 2010; Busacca, Beebe, \& Toman, 2010; and Warr, 2008).

Therefore, because many researchers have adopted various classifications for work values, it can be very difficult for researchers who hope to study work values to determine the correct 
method of concrete classification of work values. Ueda and Ohzono (2012) reviewed prior researchers' classifications of work values. They concluded,

"[C]learly, there is no consensus on the dimensionality of work values across different studies. To investigate the dimensionality of work values for people in different jobs, it is preferable to begin by asking general questions about various aspects of the work situation to determine the dimensionality of work values in an ex-post manner, rather than adopting a simple ex-ante dichotomy" (p. 99).

In this paper, we employed data collected from working persons employed by organizations in Japan during a study performed by the Recruit Works Institute (RWI). As we will later explain in detail, the questionnaire included questions related to respondents' views on work and work values. Based on this data, we initially attempted to discover the dimensions of work values. Then, we investigated the differences apparent in these work values based on basic demographical factors.

\section{Research Method}

\subsection{Database}

Recruit Works Institute (RWI) has conducted a "Working Person Survey" every two years since 2000. Recently, they released the latest data, "Working Person Survey, 2010," to the Center for Social Research Japan Data Archives (SSJDA), Institute of Social Science, University of Tokyo. Therefore, researchers who received permission from SSJDA have been able access this data. Information in the data reveals the current situations of working persons employed by a variety of organizations in Japan. The data assists researchers focused on the study of working persons to gain deeper insights into this topic.

The data used in this survey was collected from working persons (full-time, contracted, part-time, and so on) who resided within a 50-kilometer radius of the Tokyo metropolitan area (Tokyo, Kanagawa, Chiba, and Saitama Prefectures). Respondents ranged between 18 and 59 years of age. Although previous versions of this survey were conducted by the use of a placement method, on this occasion, all respondents used the Internet to provide answers to questionnaires. Some questionnaire items, including items related to the measurement of work values, were provided only to full-time working persons. Therefore, only data collected from full-time working persons was utilized for this study. The final sample size was 6,860 (3,236 (male-married), 1,677 (male-unmarried), 710 (female-married), 1,237 (female-unmarried)).

\subsection{Measurement of Work Values}

Respondents scored 34 unique questions that addressed their views of work (shigoto-kan, in Japanese) on a typical 5-point Likert scale (5 = "important"; 1 = "unimportant"). (In fact, the Likert scale used to measure original questions was reversed $(1=$ "important" to $5=$ "unimportant") based on Japanese tradition (Japanese people tend to regard "1" as the best). Thus, we reversed all responses to match a regular Likert scale prior to the analysis.) Although the original survey designers' concepts of respondents' views of work is unclear, 
almost all questionnaire items were related to the desirability of work outcomes, or to results or states that working persons hope to achieve by their work. We decided that these items would be useful measures for work values. Although the previous survey conducted by RWI (i.e., "Working Persons Survey, 2008") employed questions related to work values, the majority of those questions differed from the current questions. Therefore, a simple comparison between current and previous items was impossible.

First, we conducted an Exploratory Factor Analysis (EFA) (maximum-likelihood method, promax rotation) of the 34 selected items. We noted that two items: "5. [Work is] an activity that increases my intentions to connect with society," and "10. [Work is] an activity where my raison d'etre is recognized" had lower commonalities. Thus, we omitted two items and conducted the EFA analysis again for the remaining 32 items, and then, we achieved a satisfactory result. As shown in Table 1, four factors displayed eigenvalues over 1 . The pattern matrix shown in Table 2 illustrates that each of the original questions demonstrated relative associations with one of these four factors.

Table 1. Total Variance Explained.

\begin{tabular}{|c|c|c|c|c|c|c|c|}
\hline \multirow{2}{*}{ factor } & \multicolumn{3}{|c|}{ initial eigenvalues } & \multicolumn{3}{|c|}{$\begin{array}{l}\text { extraction sums of } \\
\text { squared loadings }\end{array}$} & \multirow{2}{*}{$\begin{array}{c}\text { rotation } \\
\text { sums of } \\
\text { squared } \\
\text { loadings } \\
\text { total }\end{array}$} \\
\hline & total & $\begin{array}{c}\% \text { of } \\
\text { variance }\end{array}$ & $\begin{array}{c}\text { cumulative } \\
\%\end{array}$ & total & $\begin{array}{c}\% \text { of } \\
\text { variance }\end{array}$ & $\begin{array}{c}\text { cumulative } \\
\%\end{array}$ & \\
\hline 1 & 11.674 & 36.48 & 36.48 & 11.149 & 34.842 & 34.842 & 9.826 \\
\hline 2 & 2.132 & 6.663 & 43.143 & 1.442 & 4.507 & 39.349 & 9.579 \\
\hline 3 & 1.689 & 5.277 & 48.419 & 1.235 & 3.861 & 43.209 & 6.442 \\
\hline 4 & 1.27 & 3.969 & 52.389 & 0.732 & 2.288 & 45.497 & 4.295 \\
\hline 5 & 0.913 & 2.854 & 55.243 & & & & \\
\hline
\end{tabular}


Table 2. Commonalities and Pattern Matrix.

\begin{tabular}{|c|c|c|c|c|c|c|}
\hline \multirow{3}{*}{ items } & \multirow{2}{*}{\multicolumn{2}{|c|}{ Communalities }} & \multicolumn{4}{|c|}{ pattern matrix } \\
\hline & & & \multicolumn{4}{|c|}{$\begin{array}{l}\text { Factor } \\
\text { (omitted coefficient of } \\
\text { less than }|0.3| \text { ) }\end{array}$} \\
\hline & initial & Extraction & 1 & 2 & 3 & 4 \\
\hline $\begin{array}{l}\text { 28. [Work allows me] to create something worthwhile } \\
\text { and unique by my efforts. }\end{array}$ & 0.512 & 0.556 & 0.762 & & & \\
\hline 12. [Work is] an activity I want to perform. & 0.376 & 0.392 & 0.716 & & & \\
\hline $\begin{array}{l}\text { 31. [Work is] an activity that allows me to create } \\
\text { something, rather than to receive something. }\end{array}$ & 0.485 & 0.516 & 0.714 & & & \\
\hline $\begin{array}{l}\text { 3. [Work is] an activity that allows me to fulfill my } \\
\text { potential. }\end{array}$ & 0.520 & 0.554 & 0.639 & & & \\
\hline $\begin{array}{l}\text { 1. [Work is] an activity that gives me a sense of } \\
\text { accomplishment. }\end{array}$ & 0.506 & 0.533 & 0.576 & & & \\
\hline 2. [Work provides] new and challenging problems. & 0.543 & 0.559 & 0.56 & & & \\
\hline $\begin{array}{l}\text { 6. [Work is] an activity that makes the impossible } \\
\text { possible. }\end{array}$ & 0.435 & 0.444 & 0.524 & & & \\
\hline 13. [Work is] an activity that is as enjoyable as a game. & 0.258 & 0.276 & 0.473 & & & \\
\hline $\begin{array}{l}\text { 15. (Work is] an activity by which I can commit myself } \\
\text { and not worry about time. }\end{array}$ & 0.431 & 0.425 & 0.472 & & & \\
\hline 4. [Work allows me] to better myself. & 0.463 & 0.469 & 0.417 & & & \\
\hline $\begin{array}{l}\text { 32. [Work allows me] to achieve more than just a } \\
\text { salary. }\end{array}$ & 0.445 & 0.444 & 0.319 & & & \\
\hline 11. [Work is] an activity that offers responsible tasks. & 0.507 & 0.505 & 0.314 & & & \\
\hline $\begin{array}{l}25 . \text { [Work allows me] to contribute to society or the } \\
\text { nation. }\end{array}$ & 0.451 & 0.497 & & 0.838 & & \\
\hline 7. [Work allows me] to perform helpful activities. & 0.518 & 0.568 & & 0.835 & & \\
\hline 8. [Work is] an activity that is appreciated. & 0.472 & 0.472 & & 0.633 & & \\
\hline 30. [Work] can solve problems in society. & 0.468 & 0.48 & & 0.547 & & \\
\hline $\begin{array}{l}\text { 33. [Work allows me] to pass something down to the } \\
\text { next generation. }\end{array}$ & 0.482 & 0.488 & & 0.544 & & \\
\hline 26. [Work allows me) to develop my organization. & 0.473 & 0.457 & & 0.489 & & \\
\hline 24. It is important to work hard. & 0.368 & 0.389 & & 0.446 & & 0.337 \\
\hline 34. [Work is] an activity that improves a person. & 0.450 & 0.441 & & 0.446 & & \\
\hline $\begin{array}{l}\text { 29. [Work allows me) to meet the expectations of } \\
\text { people with whom I work (e.g., customers, peers, and } \\
\text { supervisors). }\end{array}$ & 0.456 & 0.452 & & 0.43 & & \\
\hline 9. [Work is] an activity I perform with my peers. & 0.326 & 0.317 & & 0.377 & & \\
\hline $\begin{array}{l}\text { 21. [Work is] an activity that provides me with a } \\
\text { business title and a sense of belonging. }\end{array}$ & 0.419 & 0.524 & & & 0.763 & \\
\hline $\begin{array}{l}\text { 17. [Work is] activity that allows me to acquire the } \\
\text { authority and discretion to perform tasks. }\end{array}$ & 0.460 & 0.543 & & & 0.667 & \\
\hline
\end{tabular}


16. [Work is] an activity by which I acquire social status and recognition.

22. I am unable to find any activity worthier than work.

27. [Work allows me) to represent my company and enhance its reputation in society.

20. [Work allows me] to become financially independent.

19. [Work allows me] to support my family.

18. [(Work allows me] to acquire monetary success.

23. It is natural to work when a person becomes an adult.

The first factor demonstrated a strong relationship with questions related to "accomplishment," or "challenge," (e.g., "28. [Work allows me] to create something worthwhile and unique by my efforts," "3. [Work is] an activity that allows me to fulfill my potential," and "1. [Work is] an activity that provides a sense of accomplishment.") Work can be considered a factor in the creation or attainment of an object or a state. Therefore, we termed this factor "accomplishment." The second factor was related to questions such as " 25 . [Work allows me] to contribute to the society or the nation," "7. [Work is] an activity that is helpful to someone," and "8. [Work is]) an activity that people appreciate." Almost all of these items relate to working persons' contributions to society or to their organizations. Therefore, we termed the second factor "contribution." The contribution factor is possibly related to organizational citizenship behavior (OCB) (Organ, 1988; Organ, Podsakoff, and McKenzie, 2006). However, this factor also includes contributions made not only to organizations, but also to society. Thus, it may not necessarily be similar to OCB. The third factor demonstrated a strong relationship with items such as "17. [Work is] an activity by which I can acquire the authority and discretion to perform tasks," and "16. [Work is] an activity by which I can acquire social status and recognition." Therefore, we termed this factor "power and authority." Finally, the fourth factor was related to items such as "20. [Work allows me] to become financially independent," and "18. [Work allows me] to achieve monetary success." Therefore, we termed this factor "monetary rewards."

When we compared these work values to traditional intrinsic and extrinsic work values, we considered accomplishment and contribution should belong to intrinsic work values. Monetary rewards should be included in extrinsic work values. Although power and authority might also be considered an extrinsic work value, it maintains a relationship with intrinsic work values depending on the reason why power and authority is sought.

\section{Differences in Work Values by Gender, Marriage, and Generations}

Table 3 shows the result of a simple t-test performed to discover differences that occurred between the averages of factor scores by gender. All averages by gender were significantly different at the $0.001(0.1 \%)$ significance level. Some of the results differed from the findings of past studies. First, males had higher levels for three out of four work values (i.e., accomplishment, contribution, and power and authority) than females. It is easy to assume 
that both accomplishment and power and authority work values would be higher for males than for their female counterparts. These results agreed with the results of past studies (Croson \& Gneezy, 2009; De Pater, Van Vianen, Fischer, \& Van Ginkel, 2009; Dirilen-Gumus \& Buyuksahin-Sunal, 2012; Jansz, Avis, \& Vosmeer, 2010; Vacha-Haase et al., 1994). In contrast, we might not expect that males would have higher levels of contribution values than females. In fact, some researchers found that females had higher levels of benevolence than males (Dirilen-Gumus \& Buyuksahin-Sunal, 2012). Some studies that examined OCB also revealed similar gender effects (Diefendorff, Brown, Kamin, \& Lord, 2002; Ueda, 2012). However, Fletcher and Major (2004) discovered that both males and females achieved similar levels of altruism motives or work values. Vacha-Haase et al. (1994) discovered that male had higher levels of altruism than females. Therefore, the results we discovered for contribution appears contrary to past findings. A difference between traditional OCB and the contribution dimension appeared in the sphere of individuals' contributive behaviors. Usually, OCB is assumed to include contributions to the organization and to other working persons within the organization. On the other hand, in this article, contribution includes contributions made to other working persons both inside and outside the organization. This type of work value might be more closely associated with a sense of social mission, rather than a simple feeling of fellowship.

Finally, we might not expect that females would emphasize monetary rewards. In fact, Hirschi (2010) discovered that a contrary relationship existed. However, McDuff and Mueller (2002) found no differences in relation to emphasis on adequate pay and benefits between men and women. Further, although many males devote their lives to organizations, at times, intrinsic rewards, such as accomplishment and contribution, may be more crucial than monetary rewards. However, many females may solely work to earn money to live on.

Table 3. Results of t-test related to factor scores by gender.

\begin{tabular}{|lccrc|}
\hline \multicolumn{1}{|c}{ Factor } & male & \multicolumn{1}{c}{ female } & t-values & \multicolumn{1}{c|}{ sig. } \\
\hline Accomplishment & 0.0353 & -0.0890 & 4.965 & $<.001$ \\
Contribution & 0.0362 & -0.0912 & 5.010 & $<.001$ \\
Power and authority & 0.0663 & -0.1672 & 9.584 & $<.001$ \\
Monetary Rewards & -0.0241 & 0.0609 & -3.617 & $<.001$ \\
\hline
\end{tabular}

Table 4 displays the result of a t-test performed to discover differences that occurred between the averages of the factor scores by marital status (married, or unmarried). All levels of factor scores were significantly higher for married working persons than for their unmarried counterparts. The finding that married persons demonstrated higher levels of work values for monetary rewards was expected and understandable. Many married persons must provide financial support for their spouses and children. Therefore, they have greater interest in earning money to fulfill these obligations. It might be difficult to explain the reasons for the effects of marital status on the other three work values. Some of these effects might have resulted from respondents' ages because, on average, married persons were older than unmarried persons were (the average age of married persons was 43.11; the average age of 
unmarried persons was 34.33). We will address the effects of age later in this section.

Table 4. Results of t-test related to factor scores by marital status.

\begin{tabular}{|lrrrr|}
\hline \multicolumn{1}{|c}{ Factor } & married & unmarried & t-values & \multicolumn{1}{c|}{ sig. } \\
\hline Accomplishment & 0.0467 & -0.0632 & 4.674 & $<.001$ \\
Contribution & 0.0674 & -0.0912 & 6.805 & $<.001$ \\
Power and authority & 0.0258 & -0.0349 & 2.711 & $<.01$ \\
Monetary Rewards & 0.0367 & -0.0497 & 3.996 & $<.001$ \\
\hline N: 3,946 (married),2,914(unmarried) & & &
\end{tabular}

Table 5 shows the results of a t-test performed to discover differences that occurred between the averages of factor scores by the combination of gender and marital status. The right columns on the table illustrate cases of significant differences between the two samples. For example, "m-m>f-u" means the average of "male-married" persons was significantly higher than the average of "female-unmarried" persons, at least at a $0.05(5 \%)$ significance level. The results shown in this table are rather complicated. Therefore, a detailed investigation is required to address each of the four factors. First, with respect to accomplishment work values, males with spouses demonstrated the highest levels of work values in all categories. In addition to the finding that demonstrates that males demonstrated higher levels of accomplishment than females in Table 3, Table 5 also illustrates that the difference between male-married samples and male-unmarried samples was also significant. Therefore, marriage appears to be an important event that causes males to change their accomplishment work values. (With respect to the female sample, no significant effect was observed for marriage because the averages for female-married and female-unmarried samples showed no significant differences.) Next, males with spouses also demonstrated higher levels of contribution work values than levels in all other categories. Although Table 4 demonstrated that married persons emphasized contribution more than their unmarried counterparts, this relationship held true solely for males (no significant difference was demonstrated between female-married and female-unmarried persons). Third, no significant differences in power and authority were demonstrated between married and unmarried persons of either gender. It was clear that gender exerted a decisive effect on the differences that occurred in power and authority work values. Finally, it is interesting to note that the lowest level for monetary rewards was scored by unmarried males. However, the causal relationship between unmarried status and low monetary rewards might be difficult to infer. We first assumed that marital status influenced work values. However, it might be possible that males who inherently possess low work values for monetary rewards would choose unmarried status. 
Table 5. Results of t-test related to factor scores by gender and marital status.

\begin{tabular}{|c|c|c|c|c|c|}
\hline Factor & $\begin{array}{l}\text { male- } \\
\text { married }\end{array}$ & $\begin{array}{l}\text { male- } \\
\text { unmarried }\end{array}$ & $\begin{array}{l}\text { female- } \\
\text { married }\end{array}$ & $\begin{array}{l}\text { female- } \\
\text { unmarried }\end{array}$ & sig. (at least $5 \%$ ) \\
\hline Accomplishment & 0.0690 & -0.0298 & -0.0548 & -0.1086 & $\begin{array}{l}m-m>m-u, m-m>f-m, m-m>f-u, \\
m-u>f-u\end{array}$ \\
\hline Contribution & 0.0962 & -0.0797 & -0.0640 & -0.1068 & $m-m>m-u, m-m>f-u, m-m>f-u$ \\
\hline $\begin{array}{l}\text { Power and } \\
\text { authority }\end{array}$ & 0.0636 & 0.0714 & -0.1464 & -0.1792 & $\begin{array}{l}m-m>f-m, m-m>f-u, m-u>f-m, \\
m-u>f-u\end{array}$ \\
\hline Monetary Rewards & 0.0341 & -0.1365 & 0.0484 & 0.0680 & $m-m>m-u, f-m>m-u, f-u>m-u$ \\
\hline
\end{tabular}

$\mathrm{N}$ : 3,236 (male-married); 1,677 (male-unmarried); 710 (female-married); 1,237 (female-unmarried).

A number of past studies focused on generational differences and their effects on work values (Gursoy, Maier, \& Chi, 2008; Gursoy, Geng-Qing \& Karadag, 2012; Jin \& Roungs, 2012; Park \& Gursoy, 2012) Table 6 displays the result of a t-test performed to discover differences between the averages of four factor scores by generation. First, accomplishment work values showed a U-shaped curve as working persons aged. Second, working persons in their 50s demonstrated exceptionally higher contribution work values than all working persons in other generations. Third, in general, levels of power and authority work values increased and levels of monetary rewards work values decreased as working persons aged. However, some exceptional cases were observed. (In fact, working persons in their 40s demonstrated the lowest power and authority work values).

Table 6. Results of t-test of averages of factor scores by age.

\begin{tabular}{|lcccc|l|}
\hline \multicolumn{1}{|c}{ Factor } & $20 \mathrm{~s}$ & $30 \mathrm{~s}$ & $40 \mathrm{~s}$ & $50 \mathrm{~s}$ & \multicolumn{1}{c|}{ sig. (at least, 5\% sig. level) } \\
\hline Accomplishment & 0.0110 & -0.0109 & -0.0690 & 0.0900 & $\begin{array}{l}20 \mathrm{~s}>40 \mathrm{~s}, 20 \mathrm{~s}<50 \mathrm{~s}, 30 \mathrm{~s}<50 \mathrm{~s}, \\
40 \mathrm{~s}<50 \mathrm{~s}\end{array}$ \\
$\begin{array}{l}\text { Contribution } \\
\begin{array}{l}\text { Power and } \\
\text { authority }\end{array}\end{array}$ & -0.0050 & -0.0125 & -0.0487 & 0.0793 & $\begin{array}{l}20 \mathrm{~s}<50 \mathrm{~s}, 30 \mathrm{~s}<50 \mathrm{~s}, 40 \mathrm{~s}<50 \mathrm{~s} \\
20 \mathrm{~s}>30 \mathrm{~s}, 20 \mathrm{~s}>40 \mathrm{~s}, 20 \mathrm{~s}>50 \mathrm{~s}, \\
\text { Monetary Rewards }\end{array}$ \\
\hline
\end{tabular}

$\mathrm{N}: 2,308$ (20s); 3,007 (30s); 2,481 (40s); 2,135 (50s).

Working persons between the ages of 20 and 50 demonstrated higher levels of accomplishment work values than the levels demonstrated by working persons in their 30s or 40s. However, the reasons for this emphasis on accomplishment might differ. Working persons in their 20s also showed higher levels of power and authority and monetary rewards work values. Thus, we might assume that they wanted to undertake challenging tasks and accomplish difficult goals because they wanted greater power and authority and monetary rewards. In contrast, working persons in their 50s demonstrated lower power and authority and monetary rewards work values and higher levels of contribution work values. We consider that these individuals hoped to achieve something important for society or for their 
organization, rather than for themselves.

It is difficult to determine reasons why different generations possessed different work values. One possible reason is that working persons' work values changed as they gained experience in their organizations. Additionally, working persons might have initially possessed these original values and demonstrated them more strongly as they aged. For example, Hirschi (2008) discovered that personality factors grew more closely related to some work values as adolescents' grade-levels increased. However, it is unclear whether the same process is occurring in older generations similar to the sample examined in this study.

Finally, we adopted a step-wise regression analysis of factor scores as dependent variables to compare the effects of independent variables examined in this article. Although the adjusted coefficients of determination were low, all beta coefficients displayed in Table 7 were significant at least at a $0.05(5 \%)$ significance level. Among three demographical variables, the effects of marital status were consistently significant. In fact, when we explained the results related to the effects of marital status in Table 4 , we made brief mention of the possibilities of the effects of age. However, this result demonstrates that the effects of marital status were stronger than the effects of age on accomplishment and contribution work values. The results related to contribution were rather surprising. Although we must avoid quick conclusions, it appeared that working persons may have shifted their focus to contributions to society because they gained a better understanding of society from exposure to their spouses and children after marriage.

Table 7. Results of step-wise regression analysis (Beta coefficients).

\begin{tabular}{|l|rrr|r|}
\hline \multicolumn{1}{|c|}{ factors } & $\begin{array}{c}\text { gender } \\
(1=\text { male, } \\
2=\text { female })\end{array}$ & $\begin{array}{c}\text { marital status } \\
(1=\text { married, } 2= \\
\text { unmarried })\end{array}$ & $\begin{array}{c}\text { age } \\
(2=20 \mathrm{~s} \text { and under } \\
\text { to } 5=50 \mathrm{~s} \text { and } \\
\text { over })\end{array}$ & adjusted $\mathrm{R}^{2}$ \\
\hline Accomplishment & -0.047 & -0.044 & & 0.005 \\
Contribution & -0.041 & -0.071 & -0.092 & 0.008 \\
Power and authority & -0.117 & -0.039 & -0.071 & 0.020 \\
Monetary rewards & 0.059 & -0.094 & 0.010 \\
\hline
\end{tabular}

\section{Discussion and Conclusion}

This article established four dimensions of work values by the performance of an exploratory factor analysis of more than 6,000 persons employed by organizations located in the Tokyo metropolitan area. Further, it also depicted the effects of gender, marriage, and generation on these work values. Although some researchers have indicated that working persons' work values remain relatively stable after they graduate from school and begin work, the results of this study revealed that work values differed significantly between single and married persons, and between generations.

Working persons' changing work values can cause a number of difficult problems for human resource management in organizations. The traditional Person-Organization Fit (P-O-F) perspective emphasizes the goodness-of-fit between the work environment (e.g., rewards 
system, organizational culture, and work values) and workers' personalities and work values. However, it is almost impossible to create a work environment that is completely congruent with workers given the fact that working persons' work values change along as changes occur in their personal lives as they age.

Although Western researchers have focused on the concept of work values for more than fifty years, only a limited amount of research has focused on the analysis of work values based on data collected from Japanese working persons. Therefore, this study can inform and educate researchers who are interested in Japanese working persons and their concepts of work values. However, this study has some limitations that might be improved by future research. First, the original questions that were relied upon to examine work values in this study were rather unsystematic. Although four factors of work values were extracted for this study, we experienced some difficulties relating these work values to other dimensions of work values identified by past researchers. Further, although we performed an Exploratory Factor Analysis, performance of a Confirmatory Factor Analysis (CFA) is also required to affirm these four work values. Second, we did not discuss the relationships that exist between the selected four kinds of work values. As we mentioned previously, the meanings of accomplishment work values may differ depending on the other three work values when differences discovered between the work values of working persons in the 20s and 50s were discussed. However, other interactional relationships between work values might exist. For example, an individual's meaning for contribution might differ depending on whether $\mathrm{s} / \mathrm{he}$ also wants power and authority. Finally, the variables selected in this study to serve as influence factors are very basic. Future research should investigate the effect of many other factors on work values.

\section{Acknowledgement}

The research is financed by the Center for Asian and Pacific Studies, Seikei University.

\section{References}

Busacca, L. A., Beebe, R. S., \& Tornan, S. M. (2010). Life and work values of counselor trainees: A national survey. Career Development Quarterly, 59(1), 2-18.

Croson, R., \& Gneezy, U. (2009). Gender differences in preferences. Journal of Economic Literature, 47(2), 448-474.

De Pater, I. E., Van Vianen, A. E. M., Fischer, A. H., \& Van Ginkel, W. P. (2009). Challenging experiences: Gender differences in task choice. Journal of Managerial Psychology, 24(1), 4-28. doi: 10.1108/02683940910922519.

Diefendorff, J. M., Brown, D. J., Kamin, A. M., \& Lord, R. G. (2002). Examining the roles of job involvement and work centrality in predicting organizational citizenship behaviors and job performance. Journal of Organizational Behavior, 23(1), 93-108.

Dirilen-Gumus, O., \& Buyuksahin-Sunal A. (2012). Gender differences in Turkish undergraduate students' values. Sex Roles, 67, 559-570. doi: 10.1007/s1119901201974. 
Duffy, R. D. (2010). Spirituality, religion, and work values. Journal of Psychology and Theology, 38(1), 52-61.

Elizur, D. (1984). Facets of work values: A structural analysis of work outcomes. Journal of Applied Psychology, 69(3), 379-389. doi: 10.1037/0021-9010.69.3.379.

Fletcher, T. D., \& Major, D. A. (2004). Medical students' motivations to volunteer: An examination of the nature of gender differences. Sex Roles, 51(1), 109-114.

Gahan, P., \& Abeysekera, L. (2009). What shapes an individual's work values? An integrated model of the relationship between work values, national culture and self-construal. International Journal of Human Resource Management, 20(1), 126-147. doi: $10.1080 / 09585190802528524$.

Gursoy, D., Chi, C. G., \& Karasdag, E. (2008). Generational differences in work values and attitudes among frontline and service contact employees. International Journal of Hospitality Management, 32(1), 40-48. doi: 10.1016/j.ijhm.2007.11.002.

Gursoy, D., Maier, T. A., \& Chi, C. G. (2008). Generational differences: An examination of work values and generational gaps in the hospitality workforce. International Journal of Hospitality Management, 27(3), 448-458. doi: 10.1016/j.ijhm.2012.04.002.

Hagstrom, T., \& Kjellberg, A. (2007). Stability and change in work values among male and female nurses and engineers. Scandinavian Journal of Psychology, 48(2), 143-151. Retrieved from http://dx.doi.org/10.1111/j.1467-9450.2007.00576.x.

Hattrup, K., Mueller, K., \& Aguirre, P. (2007). Operationalizing value importance in cross-cultural research: Comparing direct and indirect measures. Journal of Occupational and Organizational Psychology, 80(3), 499-513. Retrieved from http://dx.doi.org/10.1348/096317906X130843.

Hattrup, K., Mueller, K., \& Joens, I. (2007). The effects of nations and organizations on work value importance: A cross-cultural investigation. Applied Psychology: An International Review, 56(3), 479-499. Retrieved from http://dx.doi.org/10.1111/j.1464-0597.2007.00268.x.

Hegney, D., Plank, A., \& Parker, V. (2006). Extrinsic and intrinsic work values: Their impact on job satisfaction in nursing. Journal of Nursing Management, 14(4), 272-281. Retrieved from http://dx.doi.org/10.1111/j.1365-2934.2006.00618.x.

Hirschi, A. (2008). Personality complexes in adolescence: Traits, interests, work values, and self-evaluations. Personality and Individual Differences, 45(8), 716-721. doi: 10.1016/j.paid.2008.07.018.

Hirschi, A. (2010). Positive adolescent career development: The role of intrinsic and extrinsic work values. Career Development Quarterly, 58(1), 276-287. doi: 10.1002/j.2161-0045.2010.tb00193.x.

Jansz, J., Avis, C., \& Vosmeer, M. (2010). Playing the Sims2: An exploration of gender differences in players' motivations and patterns of play. New Media \& Society, 12(2), 
235-251. doi: 10.1177/1461444809342267.

Jin, J., \& Rounds, J. (2012). Stability and change in work values: A meta-analysis of longitudinal studies. Journal of Vocational Behavior, 80(2), 326-339. doi: 10.1016/j.jvb.2011.10.007.

McDuff, E. M., \& Mueller, C. W. (2002). Gender differences in the professional orientations of Protestant clergy. Sociological Forum, 17(3), 465-491.

Organ, D. W. (1988). Organizational citizenship behavior: The good soldier syndrome. Lexington. MA: Lexington Books.

Organ, D. W., Podsakoff, P. M., \& MacKenzie, S. B. (2006). Organizational citizenship behavior: Its nature, antecedents, and consequences. Thousand Oaks, CA: Sage.

Park, J., \& Gursoy, D. (2012). Generation effects on work engagement among U.S. hotel employees. International Journal of Hospitality Management, 31(4), 1195-1202. doi: 10.1016/j.ijhm.2012.02.007.

Sanchez-Canizares, S. A., \& Fuentes-Garcia, F. J. (2010). Gender differences in entrepreneurial attitudes. Equity, Diversity, and Inclusion: An International Journal, 29(8). Doi: 10.1108/02610151011089519.

Ueda, Y. (2012). Effects of job involvement on importance evaluation of organizational citizenship behavior. International Journal of Business and Society, 13(1), 77-89.

Ueda, Y., \& Ohzono. Y. (2012). Effects of work values on work outcomes: Investigating differences between job categories. International Journal of Business Administration, 3(2), 98-111. doi: 10.5430/ijba.v3n2p98.

Vacha-Haase, T., Walsh, B. D., Kapes, J. T., Dresden, J. H., Thomson, W. A., Ochoa-Shargey, B., \& Camacho, Z. (1994). Gender Differences on the Values Scale for Ethnic Minority Students. Journal of Career Assessment, 2(4), 408-421. doi: 10.1177/106907279400200407.

Van Ness, R. K., Melinsky, K., Buff, C. L., \& Seifert, C. F. (2010). Work ethic: Do new employees mean new work values? Journal of Managerial Issues, 22(1), 10-34.

Vansteenkiste, M., Neyrinck, B., Niemiec, C.P., Soenens, B., De Witte, H., \& Van den Broeck, A. (2007). On the relations among work value orientations, psychological need satisfaction, and job outcomes: A self-determination theory approach. Journal of Occupational and Organizational Psychology, 80(2), 251-277. doi: 10.1348/096317906X111024.

Wang, C. Y., Chen, M. H., Hyde, B., \& Hsieh, L. (2010). Chinese employees' work values and turnover intentions in multinational companies: The mediation effect of pay satisfaction. Social Behavior and Personality, 38(7), 871-894. doi: 10.2224/sbp.2010.38.7.871.

Warr, P. (2008). Work values: Some demographic and cultural correlates. Journal of Occupational and Organizational Psychology, 81(4), 751-775. doi: 10.1348/096317907X263638. 


\section{Macrothink

Watts, G. A. (1992). Work values, attitudes, and motivations of women employed in administrative support occupations. Journal of Career Development, 19(1), 49-63. doi: 10.1007/BF01323004.

Zhang, D., Wang, D., Yang, Y., \& Teng, F. (2007). Do personality traits predict work values of Chinese college students? Social Behavior and Personality, 35(9), 1281-1294. doi: 10.2224/sbp.2007.35.9.1281. 